\title{
GAMBARAN TINGKAT KECEMASAN PADA ANAK KANKER SEBELUM MENJALANI KEMOTERAPI DI RUMAH SINGGAH YAYASAN PEDULI KANKER ANAK BALI
}

\author{
Putu Aristya Putri ${ }^{1}$, Kadek Cahya Utami², I Gusti Ngurah Juniartha ${ }^{3}$ \\ ${ }^{1}$ Mahasiswa Program Studi Sarjana Keperawatan Fakultas Kedokteran Universitas Udayana \\ ${ }^{2,3}$ Staff Dosen Program Studi Sarjana Keperawatan Fakultas Kedokteran Universitas Udayana \\ Alamat Korespondensi: tya9969@gmail.com
}

\begin{abstract}
Abstrak
Kanker adalah kumpulan sel yang tidak normal, tumbuh secara progresif, tidak dapat berfungsi secara fisiologis yang dapat mengancam kesehatan individu pada berbagai usia dimulai dari anak-anak hingga lansia. Kemoterapi merupakan metode yang efektif dalam mengatasi penyakit kanker pada anak, namun dapat menimbulkan kecemasan. Kecemasan yang timbul terutama pada anak menyebabkan anak tidak mau untuk kembali berobat dan menjalani kemoterapi di rumah sakit. Penelitian ini bertujuan untuk mengetahui gambaran tingkat kecemasan pada anak kanker sebelum menjalani kemoterapi di Rumah Singgah Yayasan Peduli Kanker Anak Bali. Jenis penelitian ini yaitu deskriptif dengan teknik consecutive sampling. Penelitian ini menggunakan sampel sebanyak 30 anak. Hasil penelitian didapatkan sebesar $76,7 \%$ anak mengalami tingkat kecemasan yang berat, 13,3\% anak memiliki kecemasan sedang., dan $10,0 \%$ anak mengalami kecemasan ringan. Rekomendasi dalam penelitian ini, diharapkan orang tua selalu memberikan dukungan yang penuh untuk meminimalisir tingkat kecemasan yang dirasakan oleh anak.
\end{abstract}

Kata Kunci: Anak dengan Kanker, Kecemasan, Kemoterapi

\begin{abstract}
Cancer is an abnormal cell, growing progressively, unable to function physiologically which can threaten individuals at various ages ranging from children to the elderly. Chemotherapy is an effective method of dealing with cancer in children, but can cause anxiety. Anxiety felt by children causes them to be reluctant to return the treatment and undergo chemotherapy in the hospital. This study purpose to describe the anxiety level in cancer children before undergoing chemotherapy at the Bali Children's Cancer Care Foundation House. This research was descriptive with cross sectional design using consecutive sampling technique. This research sample was 30 children. These results of this study show that $76,7 \%$ of children experienced severe levels of anxiety, $13,3 \%$ of children experienced moderate level off anxiety, and $10,0 \%$ of children experienced mild level of anxiety. Recommendations in this study are expected that parents always provide full support to minimize the level of anxiety felt by children.
\end{abstract}

Keywords: Anxiety, Chemotherapy, Children with Cancer 


\section{PENDAHULUAN}

Kanker merupakan penyakit yang dapat terjadi mulai dari anak-anak, dewasa, hingga lansia. Kanker merupakan pertumbuhan sel abnormal yang progresif dan tidak berfungsi secara fisiologis sehingga menyebabkan penyakit dengan karakteristik mutasi genetik, proliferasi sel dan pertumbuhan sel yang menyimpang (Fly \& Klaunig, 2014; McCance \& Huether, 2018).

Prevalensi kanker mengalami peningkatan setiap tahunnya termasuk kejadian kanker pada anak. Kanker memberikan kontribusi terhadap risiko kematian pada anak sebesar $12 \%$ dalam 10 tahun diagnosis (Mertens et al, 2015). Tahun 2014 ditemukan tingkat insiden kanker pada anak-anak adalah 186,6 per 1 juta anak di Amerika Serikat (Wardd, Dentis, Robins, Kohler, \& Jemal, 2014). Departemen Kesehatan Republik Indonesia (2011) menyatakan bahwa kanker termasuk dalam sepuluh besar penyakit utama yang menyebabkan kematian anak di Indonesia. Bali menjadi provinsi ketiga dengan kanker tertinggi di Indonesia yaitu memiliki sekitar 2\% diagnosis kanker oleh tenaga medis dan memiliki jumlah absolut 8.279 kasus kanker (Riskesdas RI, 2013).

Salah satu terapi yang dilakukan untuk menangani kanker yaitu kemoterapi. Namun kemoterapi dapat memberikan dampak fisik dan psikologis yang negative bagi anak. Hal tersebut terjadi karena kemoterapi merupakan terapi sistemis dengan agen sitotoksik yang dapat menghambat pertumbuhan sel yang membelah cepat baik sel kanker ataupun sel normal dalam tubuh (Hunger \& Mullighan, 2015; Wecker, 2018). Dampak fisik yang terjadi seperti nyeri, mual, kelelahan dan lain-lain, sedangkan dampak psikologisnya yaitu gangguan mood, kecemasan, harga diri rendah, dan lain-lain (Linder, Al-Qaaydeh, \& Donaldson, 2018; Hockenberry, Wilson \& Rodgers 2016). Salah satu dampak psikologis yang sering timbul akibat kemoterapi yaitu kecemasan (Lewis et al, 2016).

Kecemasan merupakan respon terhadap kondisi tertentu yang dapat mengancam diri (Kaplan, 2016). Penelitian Setiawan (2015) menjelaskan bahwa kemoterapi dapat memberikan dampak negative seperti kekhawatiran, kecemasan, serta rasa takut akibat pengalaman penyuntikan obat yang memberikan rasa tidak nyaman. Hal tersebut juga didukung oleh Arslan, Basbakkal \& Kantar (2013) yang menyatakan bahwa gejala setelah kemoterapi juga menjadi salah satu hal yang mengakibatkan kecemasan pada anak sebelum menjalani kemoterapi.

Tingkat kecemasan yang dialami anak kanker yang menjalani kemoterapi bervariasi. Penelitian Putranti (2016) menyebutkan bahwa tingkat kecemasan anak sakit kanker 71,4\%iorespondeni memiliki kecemasan sedang dan 28,6\% responden memiliki kecemasan ringan. Reaksi kecemasan pada anak yang sakit kanker timbul saat anak di diagnosa kanker untuk pertama kalinya, namun juga berlanjut hingga anak menjalani berbagai pengobatan, kemudian akan mempengaruhi respon anak selama menjalani kemoterapi. Nurhidayah, Hendrawati, Mediani, dan Adistie (2016) menyatakan anak dengan kanker mengeluhkan takut, sedih, dan khawatir jika terjadi sesuatu yang lebih buruk.

Hasil wawancara dan observasi di Rumah Singgah Yayasan Peduli Kanker Anak Bali, didapatkan bahwa 7 dariu9 anak mengalami kecemasan pasca kemoterapi seperti menangis, gelisah, dan tidak mau menjalani kemoterapi di rumah sakit. Orang tua anak menyatakan bahwa anak selalu 
mengalami kecemasan sebelum menjalani kemoterapi di rumah sakit.

Beberapa penelitian sebelumnya telah melakukan penelitian terkait gambaran tingkat kecemasan di rumah sakit. Akan tetapi, penelitian tentang tingkat kecemasan yang tidak dilakukan di rumah sakit belum banyak ditemukan. Rumah singgah ini menjadi salah satu solusi yang sangat bermanfaat bagi keluarga dengan anak yang menjalani kemoterapi. Rumah singgah adalah instansi yang berdiri atas naungan Yayasan Peduli Kanker Anak Bali yang memiliki berbagai program kerja seperti pendampingan keluarga, administrasi dan yang lainnya dengan tujuan untuk memberikan support kepada pasien kanker. Berdasarkan data tersebut, peneliti tertarik untuk mengetahui gambaran kecemasan pada anak kanker yang menjalani kemoterapi di Rumah Singgah Yayasan Peduli Kanker Anak Bali.

\section{METODE PENELITIAN}

Jenis penelitian ini yaitu deskriptif kuantitatif dengan pendekatan cross sectional pada anak kanker sebelum menjalani kemoterapi Rumah Singgah Yayasan Peduli Kanker Anak Bali.

Populasi penelitian adalah seluruh anak yang akan melakukan kemoterapi dan tinggal di Rumah Singgah Yayasan Peduli Kanker Anak Bali yaitu 41 orang. Teknik pengambilan sampel penelitian yaitu dengan metode nonprobability sampling yaitu consecutive sampling. Sampel penelitian yang terpilih yaitu 30 anak. Kriteria inklusi penelitian yaitu anak usia 6-8 tahun dengan penyakit kanker dan sedang dalam tahap pengobatan kemoterapi. Kriteria eksklusi yaitu anak yang tidak bersedia menjadi responden.

Instrument yang digunakan peneliti yaitu kuesioner karakteristik responden dan kuesioner Short Version State-Trait Anxiety Inventory-S (Short Version STAI-S) dengan 6 item pernyataan. Jumlah skor Short Version STAI-S dikalikan 20/3 sehingga nilai 20-37 diklasifikasikan ke dalam normal atau tingkat kecemasan ringan, 38-44 sebagai tingkat kecemasan sedang, dan skor 45-80 sebagai tingkat kecemasan tinggi (Kayikcioglu, Bilgin, Seymenoglu, dan Devec, 2017).

Data dikumpulkan dengan memberikan lembar kuesioner pada responden (anak dan orang tua) yang akan dipandu oleh enumerator (petugas yayasan yang bertugas 24 jam). Penelitian dilakukan satu hari sebelum individu mendapatkan kemoterapi. Prosedur penelitian dilakukan kurang lebih selama 20 menit.

Analisis yang digunakan yaitu analisis univariat dan data disajikan dalam bentuk distribusi frekuensi serta mean, median, standar deviasi, modus, minimum, dan maksimum. Penelitian ini telah mendapat surat ethical clereance dari Komisi Etika Penelitian FK Unud/RSUP Sanglah Denpasar.

\section{HASIL PENELITIAN}

Pengumpulan data pada penelitian ini dilakukan pada 5 April 2019 sampai 14 Juni 2019. Rumah singgah adalah instansi yang berdiri atas naungan Yayasan Peduli Kanker Anak Bali. Yayasan ini didirikan pada 28 April 2013 dengan visi setiap anak Indonesia yang menderita kanker memiliki hak untuk memperoleh terapi serta upaya penyembuhan yang maksimal serta mendapat hak seperti bermain dan belajar meskipun dalam kondisi yang tidak sehat. Pasien yang berkunjung ke Rumah Singgah adalah pasien anak kanker yang melakukan pengobatan di RSUP Sanglah Denpasar. Pada bulan Maret 2019 tercatat 36 anak yaitu lakilaki 21 orang dan perempuan 15oorang. 
Jenis kanker yang paling banyak yaitu leukemia dan retinoblastoma.

Tabel 1

Gambaran Karakteristik Responden Berdasarkan Usia

\begin{tabular}{|c|c|c|}
\hline Variabel & Rerata & Min-Max \\
\hline Usia & 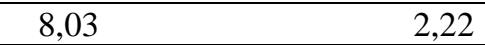 & $6-17$ \\
\hline
\end{tabular}

Tabel 2

Karakteristik Responden Berdasarkan Jens kelamin, Jenis Kanker, Dan Pengalaman Kemoterapi

\begin{tabular}{lccc}
\hline & & Frekuensi & Persentase \\
\hline \multirow{2}{*}{ Kenis } & Laki-laki & 17,0 & $56,70 \%$ \\
\cline { 2 - 4 } & Perempuan & 13,0 & $43,30 \%$ \\
\cline { 2 - 4 } & Total & $\mathbf{3 0 , 0}$ & $\mathbf{1 0 0 , 0 0 \%}$ \\
\cline { 2 - 4 } & Leukemia & 27,0 & $90,00 \%$ \\
\cline { 2 - 4 } Jenis Kanker & Retinoblastoma & 2,0 & $6,70 \%$ \\
\cline { 2 - 4 } & Kanker Tulang & 1,0 & $3,30 \%$ \\
\hline \multirow{3}{*}{$\begin{array}{c}\text { Pengalaman } \\
\text { kemoterapi }\end{array}$} & Total & $\mathbf{3 0 , 0}$ & $\mathbf{1 0 0 , 0 0 \%}$ \\
\cline { 2 - 4 } & Ya & 26,0 & $86,70 \%$ \\
\hline & Tidak & $\mathbf{3 0 , 0}$ & $\mathbf{1 0 0 , 0 0 \%}$ \\
\hline
\end{tabular}

Tabel 2 menampilkan bahwa mayoritas responden berjenis kelamin laki-laki yaitu 17 orang $(56,70 \%)$. Jenis kanker terbanyak yaitu leukemia berjumlah 27 orang (90\%) dan sebagian besar responden memiliki pengalaman kemoterapi yaitu 26 orang $(86,7 \%)$.

Tabel 3

Gambaran Tingkat Kecemasan Responden Sebelum Menjalani Kemoterapi

\begin{tabular}{clcc}
\hline & \multicolumn{1}{c}{ Frekuensi } & Persentase \\
\hline \multirow{2}{*}{$\begin{array}{l}\text { Kecemasan } \\
\text { Kecemasan }\end{array}$} & 3 & $10,0 \%$ \\
\cline { 2 - 4 } & $\begin{array}{l}\text { Ringan } \\
\text { Kecemasan } \\
\text { Sedang }\end{array}$ & 4 & $13,3 \%$ \\
\cline { 2 - 4 } & $\begin{array}{l}\text { Kecemasan } \\
\text { Berat }\end{array}$ & 23 & $76,7 \%$ \\
\hline Total & $\mathbf{3 0}$ & $\mathbf{1 0 0 , 0 \%}$ \\
\hline
\end{tabular}

Tabel 3 menampilkan bahwa mayoritas responden mengalami kecemasan berat yaitu 23 orang $(76,7 \%)$.

\section{PEMBAHASAN}

Hasil penelitian mendapatkan bahwa mayoritas responden memiliki usia dalam rentang usia 6-7 tahun. Hasil ini sesuai dengan penelitian Nurhidayah, Hendrawati, Mediani, dan Adistie (2016) yang menemukan pasien anak dengan kanker berada pada mayoritas usia 5 hingga 18 tahun. Hal yang sama juga didapatkan oleh penelitian lain yang menyatakan bahwa mayoritas atau sebesar $75 \%$ anak yang menderita kanker berada pada usia 5 hingga 18 tahun (Novrianda \& Arif, 2018).

Hasil penelitian menemukan mayoritas responden berjenis kelamin laki-laki. Penelitian yang dilakukan oleh Marcdante, Kliegman, Jenson \& 
Behrman (2014) dan Wolley, Gunawan, \& Warouw (2016) menemukan bahwa pasien anak laki-laki yang terdiagnosis kanker lebih dominan dari pada anak perempuan. Akan tetapi, beberapa penelitian sebelumnya membuktikan bahwa tidak ada hubungan kejadian kanker pada anak dengan jenis kelamin (Baumester, Aktar, Ciufolni, Pariamte, \& Mondeli, 2016; Pei et al, 2016).

Sebagian besar anak mengalami kanker jenis leukemia yaitu $90 \%$. Hasil ini serupa dengan penelitian Ward, DeSantis, Robbins, Kohler, dan Jemal (2014) yang menyatakan bahwa mayoritas anak mengalami kanker leukemia. American Cancer Society (2015) menyatakan bahwa leukemia menyumbangkan sebesar 30 persen prevalensi kanker pada anak. Leukemia pada anak belum diketahui penyebabnya secara pasti, akan tetapi diperkirakan hal tersebut dapat terjadi akibat interaksi 4 faktor risiko, yaitu genetik, zat kimia, virus, dan radiasi (Voûte, Barrett, Bloom, Lemerle \& Neidhardt, 2012).

Sebagian besar anak memiliki pengalaman kemoterapi yaitu $76,7 \%$. Pengalaman merupakan hal yang sangat berpengaruh signifikan terhadap keberhasilan terapi pada anak kanker (Gonzalez, Mercado, Williams, Williams, Pedro \& Colon, 2017). Pengalaman anak terhadap masa pengobatan erat dikaitkan dengan kualitas hidup anak kanker. Anak yang memiliki pengalaman kemoterapi cenderung sudah terbiasa dengan pengobatan rutin yang dilakukan dan mempunyai mekanisme adaptasi koping yang baik (Momani, Hathaway \& Mandrell, 2016).

Sebagian besar responden mengalami kecemasan dengan kategori kecemasan berat yaitu $76,7 \%$. Kecemasan tersebut dirasakan akibat takut dengan jarum suntik, merasa sakit akibat tertusuk jarum yang terusmenerus, takut dengan petugas kesehatan dan keramaian di rumah sakit, serta takut akan prosedur kemoterapi yang membutuhkan waktu yang lama. Rasa takut yang dialami oleh anak ini membuat anak merasa cemas setiap datang ke rumah sakit untuk pengobatan selanjutnya.

Susanti (2013) dan Fitriani, Santi \& Rahmayanti (2017) juga menjelaskan bahwa sebagian besar anak yang terdiagnosis kanker dengan pengobatan kemoterapi memiliki kecemasan tingkat berat. Perasaan cemas yang dialami anak sebelum menjalani kemoterapi tergolong kecemasan yang bersifat situasional yaitu sumber kecemasan yang dikaitkan dengan aktivitas atau kejadian tertentu (Levitt, 2015). Kecemasan tersebut biasanya muncul akibat kekhawatiran terhadap prosedur kemoterapi yang akan dijalani dan efek samping yang dapat ditimbulkan (Limbers \& Larson, 2016). Efek tersebut yaitu rasa nyeri, kesedihan, kelelahan, mual munah, kehilangan rambut, diare, konstipasi, gangguan tidur, ketakutan akan perburukan kondisi dan lain-lain (Abdelaziz \& Mona, 2017; Iyer, Balsamo, Bracken \& Kadan-Lottick, 2015).

Hasil wawancara menunjukkan bahwa sebagian besar anak mengalami kelemahan, keletihan, kehilangan rambut, penurunan berat badan, lengan serta kaki lebam, dan terdapat anak yang mengalami perburukan kondisi akibat pengobatan kemoterapi. Gangguan psikologis juga sering dialami oleh anak salah satunya kecemasan. Anak-anak biasa mengurangi rasa cemas dengan cara bermain bersama anak-anak lainnya.

Pengalaman kemoterapi menjadi faktor dalam kejadian cemas pada anak. Hal tersebut berkaitan dengan 
mekanisme koping adaptif yang dimiliki berdasarkan pengalaman (Momani, Hathaway \& Mandrell, 2016). Akan tetapi, hasil penelitian ini menunjukkan anak yang memiliki pengalaman kemoterapi sebelumnya juga masih memiliki tingkat kecemasan yang tinggi. Hal tersebut dikarenakan adanya pemikiran rasa takut akan penerimaan rasa sakit yang diterima anak saat menjalani proses kemoterapi.

Pola koping juga mempengaruhi rasa cemas bagi anak. Perkembangan pola koping anak cenderung mengalami kendala karena anak diharuskan melakukan pengobatan berulang sehingga pola koping yang terbentuk cenderung maladaptif. Hasil analisis yang dilakukan peneliti, sebagian besar anak mengalami kecemasan ketika hendak menjalani prosedur kemoterapi melalui jalur intravena karena anak takut akan nyeri yang dapat ditimbulkan oleh prosedur invasif. Rasa nyeri yang diterima anak saat kemoterapi melalui jalur intravena memberi pengaruh besar terhadap psikologis anak sehingga membuat anak merasa takut (Bennett, 2016; Rasjidi dalam Rata, Basit \& Anggraini, 2018).

Dukungan keluarga juga memberikan pengaruh yang signifikan terhadap rasa cemas. Ketika orang tua merasakan kecemasan mengenai anak, hal tersebut secara tidak langsung memengaruhi pola asuh anak sehingga menyebabkan penurunan dukungan emosional terhadap anak (Huang, et al., 2018). Dukungan sosial dapat mengurangi cemas yang dialami pada anak karena anak merasa mendapat perlindungan (Putranti \& Susilaningsih, 2016).

Anak yang hendak menerima kemoterapi terbukti mengalami kecemasan dengan kategori berat. Keliat (2011) menjelaskan bahwa kecemasan diartikan sebagai sebuah perasaan was-was dan merasa adanya ancaman sehingga muncul gejala jantung berdebar, adanya pengeluaran keringat dingin, tangan gemetar, rewel, mengamuk, atau bahkan menolak untuk menerima tindakan meskipun dalam jadwal pengobatan (Nazari, et al., 2017).

\section{KESIMPULAN DAN SARAN}

Simpulan penelitian menunjukkan bahwa mayoritas anak yang terdiagnosis kanker mengalami rasa cemas dengan kategori kecemasan berat sebelum menjalani kemoterapi.

Penelitian ini memiliki beberapa keterbatasan, sehingga peneliti menyarankan kepada peneliti selanjutnya agar mengidentifikasi lebih banyak jenis kanker pada subjek penelitian agar mendapat variasi data. Yayasan Anak Kanker Bali juga sebaiknya menyediakan intervensi salah satunya permainan terapeutik yang bertujuan untuk mengatasi kecemasan pada pasien anak yang terdiagnosis kanker dan menjalani kemoterapi. Peneliti ingin mengucapkan terima kasih kepada seluruh pihak yang telah membantu pelaksanaan penelitian ini.

\section{DAFTAR PUSTAKA}

Abdelaziz, M. T., \& Mona, M. (2017). The relationship between PTSD, Anxiety and Depression in Palestinian children with cancer and mental health of mothers. J Psychol Brain Stud, 1(2), 9.

American Cancer Society. (2015). A guide to chemotherapy. American Cancer Society.

Arslann, F. T., Basbakal, Z., \& Kanter, M. (2013). Quality of life and chemotherapy-related symptoms of Turkish cancer children undergoing chemotherapy. Asian Pacific Journal of cancer prevention, 14(3), 17611768.

Baumester, D., Aktar, R., Ciufolni, S., Parinte, C. M., \& Mondelli, V. (2016). Childdhood trauma and adulthood 
inflamation: a metanalysis of peripheral C-reactive protein, interleukin-6 and tumor necrosis factor- $\alpha$. Molecular psychiatry; 21(5), 642.

Bennett, M. (2016). Pain management for chemotherapy-induced oral mucositis. Nursing children and young people, 28(10).

Departemen kesehatan Republik Indonesia. (2011). Press releasee hari kanker anak sedunia. Accessed at http://www.tvl.com/pressreleaseharika nkeranaksedunia on September $15^{\text {th }}$ 2018.

Fitriani, W., Santi, E., \& Rahmayanti, D. (2017). Terapi Bermain Puzzle terhadap Penurunan Tingkat Kecemasan pada Anak Usia Prasekolah (3-6 Tahun) Yang Menjalani Kemoterapi Di Ruang Hematologi Onkologi Anak. Dunia Keperawatan, 5(2), 65-74.

Fly, A. D., \& Klaunig, J. E. (2014). Cancer During Childhood. Encyclopedia of Primary Prevention and Health Promotion, 581-587.

Gonzalez-Mercado, VJ., Williams, PD., Williams, A. R., Pedro, E., \& Colon, G. (2017). The symptom experiences of Puerto Rican children undergoing cancer treatments and alleviation practices as reported by their mothers. International journal of nursing practice, 23(1), e12500.

Hockenbery, MJ., Wilson, D., \& Rodgers, CC. (2016). Wong's Essentials of Pediatric Nursing-E-Book. Elsevier Health Sciences.

Huang, I. C., Brikman, T. M., Mulins, L., Pui, C. H., Robison, L. L., Hudson, M. M., \& Krull, K. R. (2018). Child symptoms, parent behaviors, and family strain in long-term survivors of childhood acute lymphoblastic leukemia. Psycho-Oncology, 27(8), 2031-2038.

Hunger, SP., \& Mulighan, CG. (2015). Acute lymphoblastic leukemia in children. New England Journal of Medicine, 373(16), 1541-1552.

Iyer, NS., Balsmo, LM., Bracken, MB., \& Kadan-Lottick, N. S. (2015). Chemotherapy only treatment effects on long term neurocognitive functioning in childhood ALL survivor: a review and meta-analysis. Blood, 126(3), 346-353.
Kaplan, S. (2016). Textbook of psychiatry. Philadelphia: Williams and Wilkins.

Kayikcoglu, O., Bilgin, S., Seymnoglu, CG., Devec, A. (2017). State and trait anxiety scores of patients receiving intravitreal injections. Biomed Hub 2017, 2, 1-5, 478993. DOI: $10.1159 / 000478993$.

Keliat, BA. (2011). Manajemen kasus gangguan jiwa. Jakarta: EGC.

Levitt, EE. (2015). The psychology of anxiety. Routledge.

Lewis, SL., Bucher, L., Heitkmper, MM., Harding, M. M., Kwong, J., \& Roberts, D. (2016). Medical-Surgical NursingE-Book: Assessment and Management of Clinical Problems, Single Volume. Elsevier Health Sciences.

Limbers, C. A., \& Larson, M. (2016). A systematic review of psychometric properties of the Pediatric Quality of Life Inventory ${ }^{\mathrm{TM}} 4.0$ generic core scales: in pediatric cancer patients and survivors. Expert Review of Quality of Life in Cancer Care, 1(2), 145-152.

Linder, LA., Al-Qaadeh, S., \& Donaldson, G. (2018). Symptom characteristics among hospitalized children and adolescents with cancer. Cancer nursing, 41(1), 23-32.

Marcdante, KJ., Kligman, R., Jenson, HB., \& Behrman, RE. (Eds.). (2014). Nelson ilmu kesehatan anak esensial. Elsevier.

McCance, KL., \& Hueter, SE. (2018). Pathophysiology-E-Book: The Biologic Basis for Disease in Adults and Children. Elsevier Health Sciences.

Merten, AC., Yong, J., Dietz, AC., Kreiter, E., Yasui, Y., Bleyer, A., ... \& Wasilewski-Masker, K. (2015). Conditional survival in pediatric malignancies: analysis of data from the Childhood Cancer Survivor Study and the Surveillance, Epidemiology, and End Results Program. Cancer, 121(7), 1108-1117.

Momani, TEG., Hathaway, DK., \& Mandrell, B. N. (2016). Factors affecting healthrelated quality of life in children undergoing curative treatment for cancer: a review of the literature. Journal of Pediatric Oncology Nursing, 33(3), 228-240.

Nazari, B., Bakshi, S., Kabodi, M., Deghan, F., Ziapour, A., \& Montazeri, N. (2017). A comparison of quality of life, anxiety and depression in children with cancer and healthy children, Kermanshah, 
Iran. International Journal of Pediatric; 5(7), 5305-5314.

Novrianda, D., \& Arif, Y. (2018). Mukositis oral dan kualitas hidup spesifikmukositis oral pada anak kanker yang di kemoterapi. NERS Jurnal Keperawatan, 13(1), 50-59.

Nurhidayah, I., Hendrawti, S., Medanii, H. S., \& Adistie, F. (2016). Kualitas Hidup pada Anak dengan Kanker. Jurnal Keperawatan Padjadjaran, 4(1).

Pei, JS., Hsu, PC., Chou, AK., Tsai, CW., Chang, WS., Hsiao, CL., ... \& Bau, D. T. (2016). Matrix metalloproteinase 1 genotype contributes to the risk of non solid tumor in childhood leukemia. Anticancer research, 36(10), 51275132.

Putranti, E. (2016). Pengaruh dukungan keluarga terhadap tingkat kecemasan anak sakit kanker di RSUD Dr. Moewardi Surakarta. (Skripsi tidak dipublikasikan). Fakultas Ilmu Kesehatan Universitas Muhammadiyah Surakarta.

Putranti, E., Susilaningsih, E. Z., \& Kp, S. (2016). Pengaruh Dukungan Keluarga Terhadap Tingkat Kecemasan Anak Sakit Kanker di RSUD Dr. Moewardi Surakarta (Doctoral dissertation, Universitas Muhammadiyah Surakarta).

Rata, N. S., Basit, M., \& Anggraini, S. (2018). Hubungan dukungan emosional keluarga dengan tingkat nyeri pada anak acute lymphoblastic leukemia akibat kemoterapi. Jurnal Keperawatan Suaka Insan (JKSI), 3(1), 1-13.

Riset Kesehatan Dasar (Riskesdas). (2013). Sebaran kanker di Indonesia. Jayakarya: Pusat Penelitian Sumber Daya dan Pelayanan Kesehatan Kemenkes RI.

Setiawan, SD. (2015). The effect of chemotherapy in cancer patients to anxiety. J Majority; 4(4);: p 94-99.

Susanti, E. T. (2013). Hubungan frekuensi hospitalisasi dengan kecemasan anak leukemia usia pra sekolah saat dilakukan tindakan invasif di RSUD Dr. Moewardi. Naskah Publikasi, 1-11.

Voûte, PA., Barret, A., Blom, H. J. G., Lemele, J., \& Neidardt, M. K. (Eds.). (2012). Cancer in children's: clinical management. Springer Science \& Business Media.
Ward, E., DeSntis, C., Robins, A., Koher, B., \& Jemalk, A. (2014). Childhood and adolescent cancer statistics, 2014. $C A$ : a cancer journal for clinicians, 64(2), 83-103.

Wecker, L. (2018). Body's human pharmacology e-book. Elsevierr Health Science.

Wolley, N. G., Gunawan, S., \& Warouw, S. M. 2016). Perubahan status gizi pada anak dengan leukemia limfoblastik akut selama pengobatan. e-Clinicc; 4(1). 